\title{
Ottawa in Africa, een impressie Kaapstad 1-3 maart 2000
}

\author{
R.P. Zwierstra
}

Lathula! Met deze kreet kondigt men in Zuid Afrika de komst van een bijzondere gebeurtenis aan. Deelnemers aan de Ottawa-conferenties in Maastricht en Philadelphia, de AMEE-congressen in Praag en Linköping zijn door Athol Kent met deze kreet opmerkzaam gemaakt op Ottawa in Africa.

Ottawa in Africa, de negende International Ottawa Conference on Medical Education, was in meerdere opzichten een bijzondere gebeurtenis. Door de structuur van de conferentie, de onderwerpen, de kwaliteit van de bijdragen, het deelnemersaantal (meer dan 600, inclusief een grote Nederlandse delegatie) en de ambiance, onderscheidde deze conferentie zich van voorgaande bijeenkomsten.

De organisatie van de Ottawa-conferenties is in handen van een lokale initiatiefnemer, in dit geval Athol (the shirt) Kent, zulks in goed overleg met de mannen van het eerste uur: Ian Hart en Ronald Harden, de Otties van de Medical Educational World. Er was voor gekozen om alle ingezonden papers toe te laten tot de conferentie en een indeling te maken in vier groepen: keynote lectures (45 minuten), oral presentations (10 minuten), thematic sessions waar posters gedurende 2 minuten konden worden toegelicht, en posters. Deze systematiek en het grote aantal presentaties leidde tot 7 plenaire zittingen, meer dan 100 oral presentations, 300 thema-presentaties in 10 parallelle sessies en nog eens 64 additionele posters. Het is de vraag of men, bij een dergelijk groot aanbod, het bos tussen de bomen nog wel kan ontwaren. Met een kritische blik in het programmaboek en taakverdelingsafspraken met collegae kan men toch wel een heel eind komen, zoals uit dit verslag zal blijken.

Streng verboden voor studenten, boete 30 rand! luidde het opschrift van een verkeersbord op de campus van de University of Cape Town. Een verfrissende manier om met studenten om te gaan in een onderwijsomgeving. Die onderwijsomgeving werd op originele wijze vorm gegeven door de openingsceremonie waar behalve de verplichte hoogwaardigheidsbekleders ook twee docenten aanwezig waren, die met elkaar in debat gingen. Beide sprekers kruisten de degens over de zin en onzin van de wenselijkheid van een mondiaal curriculum geneeskunde. Na twee ronden van vlammende betogen werd door de zaal gestemd: onwenselijk. Een goede toepasselijke opening van een congres waar het vaker over opinievorming zou gaan.

Bij de bestudering van het programma valt in de eerste plaats op dat er een grote overlap van onderwerpen uit het veld van 'undergraduate' en 'postgraduate' training bestaat, een fenomeen dat in onze Nederlandse Vereniging voor Medisch Onderwijs (NVMO) nog te weinig wordt waargenomen. Verder blijkt er veel belangstelling voor multiprofessional teaching te bestaan en neemt de anatomie, wanneer het om 'basisvakken' in het medisch onderwijs gaat, op dit congres een prominente plaats in. Informatie- en communicatietechnologie (ICT) krijgt geen overmatige aandacht en daarmee de plaats die het verdient. Vergeleken met voorgaande Ottawa conferenties is het 
aantal bijdragen over psychometrische onderwerpen gering in aantal.

Opmerkelijk was dat drie sessies gewijd waren aan wat eerder wel Continuous Medical Education werd genoemd. In die bijeenkomsten werden ervaringen uitgewisseld over motivatie, methoden en resultaten. Het accent lag ook hier op een nadrukkelijke koersverandering in de richting van continuous professional development. Hierin wordt veel meer naar de effecten van de gevolgde cursussen of andere nascholingsinspanningen gekeken dan naar het alleen volgen ervan. Deze ontwikkeling heeft consequenties voor het curriculum van medisch studenten: laat ze er vroeg aan wennen.

Workshop! Een zaaltje met veertig deelnemers, een workshopleider en vier voorzitters, die beperkte instructie vooraf kregen. Workshopleider Peter McCorie is in de twee uur durende workshop niet langer dan tien minuten aan het woord. Over rolmodellen gesproken. Het onderwerp was multiprofessional teaching (MPT). Na een kort rondje voor- en nadelen, kenmerken en vooroordelen werd duidelijk dat wat de een als utopie ziet, door de ander wordt afgeschilderd als bedreigend, verlies van professionele identiteit, uitlokken van rivaliteit. Uit de tafelgesprekken aan de hand van opdrachten bleek dat, hoewel de bewijzen ontbreken, er veel voor te zeggen valt delen van opleidingen samen uit te voeren wanneer daarbij duidelijke doelen, ook in de beroepsuitoefening, voor ogen staan. MPT is te verwezenlijken wanneer er een multiprofessionele staf meedoet, studenten getoond wordt dat het in de praktijk werkt, het zowel in de undergraduate als in de postgraduate setting aandacht krijgt, deelname in een echt team onderdeel is van de training en het functioneren in een team ook wordt beoordeeld.

Generic health care skills (communicatie, ethiek, teamwork, reflectievermogen,
Acute Life Support), die tot het kerncurriculum van verschillende opleidingen behoren, kunnen heel goed samen worden gevolgd. McCrorie eindigde met een acroniem voor een patiëntgeoriënteerd consultatiemodelletje, dat voor vele gezondheidszorgberoepsgroepen bruikbaar is: Concerns, Reasons for consultation, Ideas of the patient, Meaning and Expectations. Een CRIME om dit schema niet toe te passen.

Ook in Kaapstad aandacht voor BEME: Best Evidence Based Medical Education. Twee belangrijke momenten werden hieraan gewijd: een workshop en een keynote lecture. Norman stelde in de workshop ter discussie wat de reden is waarom de methoden die in biomedische research worden gebruikt, niet in het onderwijs worden toegepast. Men praat elkaar na en doet elkaar na, bijvoorbeeld met PBL, 'adult learning principles' en het afnemen van interviews om de geschiktheid van studenten vast te stellen, terwijl bewijzen niet of nauwelijks voorhanden zijn. Het is net als met de kleren van de keizer. Hij pleit voor een beweging van 'opinion based teaching' naar 'evidence based teaching'. Vervolgens worden instrumenten aangereikt om publicaties in te schatten op kwaliteit en ook daar verschijnt weer een (redelijk) bruikbaar acroniem op het toneel: QUESTS, Quality is Utility + extent of the Evidence + Strength of the evidence + Target of the outcome measurement + the Setting. Daarna werd dit instrument toegepast op een aantal artikelen. Dat oefenen bleek pas echt nuttig, daarmee werd een aantal zwakke punten van QUESTS blootgelegd: verstaat iedereen onder utility methodologie of de bruikbaarheid als onderwijskundige methode? Nuttige workshop voor zowel de bewustwording over het onderwerp als voor het nadenken over criteria.

De keynote lecture waarin BEME een rol speelde, was die van Cees van der 
Vleuten. Hij sprak over 'Assessments next challenge'. In een wederom briljant betoog qua inhoud, vormgeving en voordracht (ovationeel applaus) hield hij de deelnemers voor dat behalve evidence bij het gebruik van toetsmethoden vooral ook de haalbaarheid (uitvoerbaarheid) een grote rol moet spelen. Aan de hand van een gemodificeerde piramide van Miller gaf Van der Vleuten aan dat de veranderende doelen in het curriculum ook vertaald dienen te worden in aanpassing van de toetsmethoden. Wanneer deze koppeling niet wordt gemaakt, zal de poging tot ingezette paradigmaverandering (naar student centered learning) niet slagen. Ik raad de lezer aan deze voordracht na te lezen op: www.unimaas.nl.

Over dit congres valt veel te vertellen: van 'teaching and telling' naar 'learning and applying' en van 'science to practice' naar 'in practice with science'. Deze slogans maakten onderdeel uit van een van de twee afsluitende lezingen door John Bligh en Ian Hart. In de komende jaren komt het accent te liggen op het beoordelen en toetsen van competentie, op de ondersteuning van het curriculum met ICT (en niet de overname door), en het gebruik van portfolio's door studenten en docenten bij de beoordeling en toetsing van prestaties. Hart besloot met een uit- eenzetting over de wijze waarop de Ottawa-conferenties worden georganiseerd en daarmee de succesfactor. In 2002 op naar Ottawa voor de tiende Ottawa conferentie.

Wat maakt een congres, zoals dit, succesvol? Voor de deelnemers als groep de educatieve waarde, de organisatie, de mogelijkheid voor sociale contacten en last but not least de omgeving. Voor een individu gaat het vooral om de kans te presenteren en om met collegae uitgebreid van gedachten te wisselen. Heeft Ottawa in Africa hieraan voldaan? Het niveau was in het algemeen goed, de organisatie prima, vele mogelijkheden tot sociale contacten in een unieke omgeving. En de individuen? Die hebben voldoende kansen geboden gekregen. Alle reden om over twee jaar (30 juni tot 3 juli 2002) naar Ottawa te reizen.

You not only have to know what kind of disease the patient has.

You have to know what kind of patient the disease has!

Osler

\section{Correspondentieadres}

Prof. dr. R.P. Zwierstra, directeur Onderwijsinstituut, Faculteit der Medische Wetenschappen, Ant. Deusinglaan 1, 9713 AV Groningen, tel. (050) 36325 46, Fax (050) 36373 90, e-mail:r.p.zwierstra@med.rug.nl. 